\title{
Strategic alliances in container shipping: A review of the literature and future research agenda
}

\section{Mohammad Ghorbani $^{1,2} \cdot$ Michele Acciaro $^{1} \cdot$ Sandra Transchel $^{1} \cdot$ Pierre Cariou $^{2}$}

Accepted: 7 December 2021 / Published online: 8 February 2022

(c) The Author(s) 2022

\begin{abstract}
Strategic alliances are the most common type of collaboration agreement used by shipping lines to provide worldwide maritime container transport services. Since their first appearance just before the mid-1990s, they have progressed to account for $90 \%$ of global container shipping capacity with the top eight container operators organizing today their East/West route services through one of the main three strategic alliances. This paper reviews comprehensively and critically the literature on the subject, over 25 years of research on this topic. This includes 85 articles published in peer-reviewed journals between 1994 and 2019, and analyzed and grouped into three main research areas: formation, management, and optimization of strategic alliances. The output of the analysis is then used to provide a future research agenda.
\end{abstract}

Keywords Container shipping · Strategic alliances · Operational collaboration · Liner shipping $\cdot$ Vessel sharing

\section{Introduction}

The liner shipping industry is organized through commercial services offered by container shipping operators (hereafter carriers) to shippers, on fixed routes, and regular schedules between ports connected via containerships (Haralambides 2019). Following the advent of containerization in the second half of the 1950s-one of the main enablers of international trade and worldwide cargo distribution-, container transportation services have experienced very rapid growth from 30 million TEUs in 1990 reaching 100 million TEUs in 2007 and about 143 million TEUs in 2020 (UNCTAD 2020).

Michele Acciaro

michele.acciaro@the-klu.org

1 Hapag-Lloyd Center of Shipping and Global Logistics (CSGL), Kühne Logistics University (KLU), Hamburg, Germany

2 Kedge Business School, Center of Excellence in Supply Chain (CESIT), Bordeaux, France 
To accommodate this impressive growth, carriers took advantage of various forms of collaboration (Thanopoulou et al. 1999; Cariou 2008), such as agreements on price (i.e., maritime conferences) and on capacity (i.e., pools, consortia), as well as through vertical collaboration along the supply chain, with such actors as ports and inland hauliers. Since 1994, with the globalization of shippers and their requirements for global carriers to provide worldwide services, liner shipping Strategic Alliances (hereafter SAs) have developed side by side with consortia and represent today a widely used form of horizontal operational co-operation (Merk and Teodoro 2022). SAs in shipping are similar to consortia but the SA agreement between carriers is generally for a wider range of routes and services, while consortia are usually more restrictive in their scope. They are, however, still regulated in most jurisdictions in the same way, for instance in Europe, by the Consortia Block Exemption Regulation (CBER), and in the USA under the oversight of the Federal Maritime Commission. Compared with Slot Charter Agreements (SCAs) and Vessel Sharing Agreements (VSAs), which are forms of operational cooperation that are usually focusing on a specific service or region of the world, SAs are global in nature encompassing multiple trade lanes. They are so important today, that the top eight container lines that account for $79.4 \%$ of global container shipping capacity are all operating within one of the three global SAs (Alphaliner 2020).

SAs are a form of horizontal collaboration that is, in its general definition (Bahinipati et al. 2009), "a business agreement between two or more companies that belong to the same level of the supply chain or network". In liner shipping, SAs focus primarily on operational aspects. Within these types of agreement, carriers are authorized to exchange information such as operational data on vessels and terminals, schedule performance, productivity reports, and standard port charges. This information helps carriers to make operational decisions pertaining to supply of vessels and their utilization on trade lanes under the geographical scope of their agreements. To secure competition and comply with antitrust laws, SA members cannot exchange information on prices, freight rates, customer lists, marketing plans, and their individual bids on shippers' container transportation auctions (Ocean alliance FMC $^{1}$ agreement 2019). In Europe, SAs have been included in the Consortia Block Exemption Regulation (BER) since 1995, which has been renewed every 5 years since its revision in 2009. In the United States, consortia and other types of cooperation agreements can become effective after a filing to the Federal Maritime Commission (FMC) without the necessity to obtain prior approval. It is thus incumbent upon the FMC to evaluate whether an agreement has adverse effects on competition (Merk 2018).

The motivations for joining SAs are many. Carriers, by means of SAs, benefit from economies of scale or scope, and improve vessel capacity utilization (e.g., Cariou and Guillotreau 2021; Haralambides 2019). Having access to more containerships improves service frequencies and expands global service coverage.

\footnotetext{
1 . The United States Federal Maritime Commission (FMC) is an independent federal agency based in Washington, D.C. that is responsible for the regulation of ocean borne international transportation of the U.S.
} 
Notwithstanding their prevalence, alliances are complex agreements to manage, and their stability is of great importance to carriers and shippers. The literature can offer valuable insights to managers on how to develop more stable agreements and better allocate the benefits of SA among partners. Furthermore, the collaborative nature of these agreements in a competitive industry and the complexity associated with modeling and analyzing the consequences of such operational arrangements have warranted a continued academic interest.

In the last decades, limited efforts have been made to bring together and systematize the knowledge available in academic journals through a comprehensive literature review, although reports and regulatory documents have contributed to advance knowledge on the topic (e.g., Merk 2018). To facilitate the identification of neglected essential research areas and operational problems, our review of the literature summarizes 25 years of research on SAs and is used to generate a discussion around the three following research questions (RQs):

RQ1 What aspects of alliance collaborations in the liner shipping industry have been studied?

RQ2 What are the main findings of these studies?

RQ3 What are the main research gaps in the literature?

To do so, we structure our literature review in four main areas of investigation based on a structured literature review of 85 selected peer-review articles published from 1994 to 2019 and presented in specific sections of the paper under the main headings: The formation of SAs, The management of SAs, and The optimization of $S A s$. The remainder of the paper has the following structure. Section 2 presents the methodology, the paper selection, and the taxonomy of research on SAs. Section 3 discusses the main findings of the literature on the formation of SAs; then Sect. 4 on the management of SAs, and finally Sect. 5 on the optimization of SAs. Section 6 concludes with a potential future research agenda.

\section{Paper selection and preliminary taxonomy}

The selection of research papers on SAs and the identification of research gaps follow a three-step procedure as presented in Fig. 1. The initial selection (Fig. 2) is based on six electronic scholarly databases (Google Scholar, Web of Science, Springer, Taylor \& Francis Online, Informs, and Scopus) and six keywords (liner shipping, container shipping, strategic alliances, vessel sharing, slot exchange, and horizontal collaboration). The keywords were individually used and combined in pairs, and the selection of the papers was restricted to articles in English, published between 1994 and 2019. The choice of focusing on publications after 1994 corresponds to the date of the creation of the first SA (September 1994). Although SAs have evolved from consortia, the justifications on the need for 


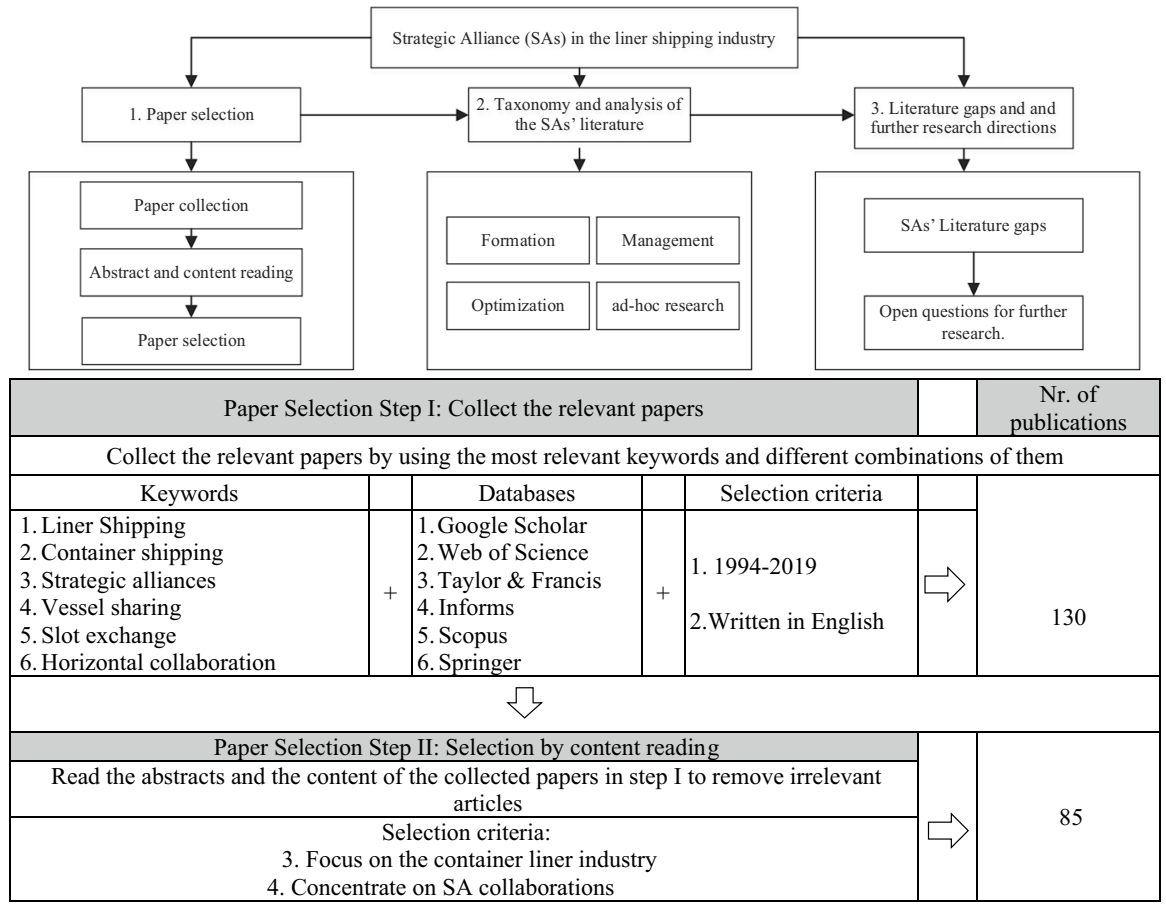

Fig. 1 The framework of the article. Source Authors

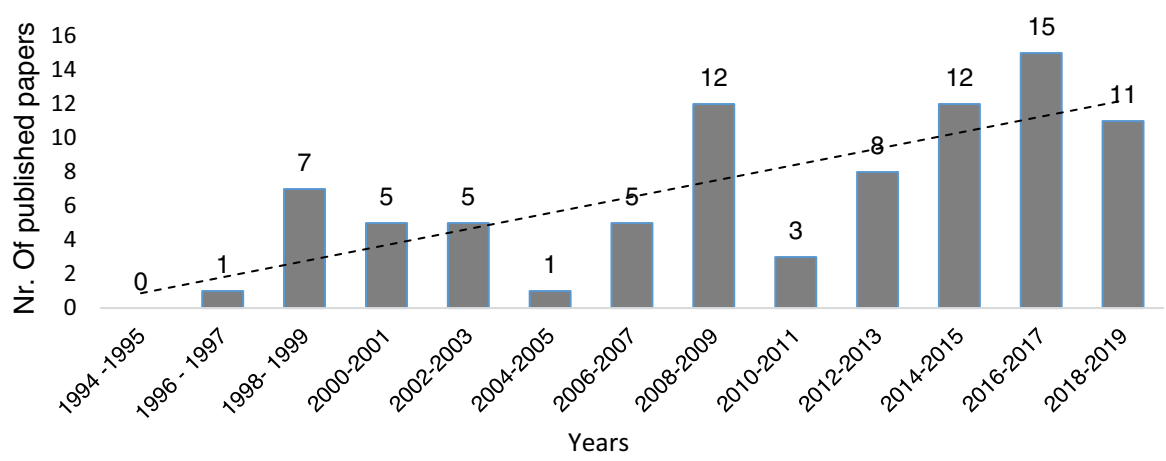

Fig. 2 The number of published articles (1994-2019). Source Authors

technical collaboration can also be found in prior research. The first step in the review led to the identification of 130 publications. We then proceeded to further analyze the literature by content reading. The main criterion adopted was that papers should focus on the container liner industry and SA collaborations. This allowed us to exclude papers concentrating on other modes of transport and/or other forms of horizontal collaboration. 
Our final selection comprised 85 papers published between 1994 and 2020. Academic research on SAs mostly appears in few specialized journals in maritime transport and economics, with Maritime Policy and Management (14 articles), Maritime Economics \& Logistics (six articles), and Transportation Research Part E (five articles) representing more than $29 \%$ of all contributions. Table 1 illustrates in more detail the number of publications in each academic journal.

Figure 2 shows that the topic of SAs has attracted attention over the years. In particular, almost half of all publications on the subject (38 papers), were published in 2008 and from 2014 to 2019. Likely reasons for the increasing focus on SAs in 2008 are related to the repeal of the EU antitrust exemption that effectively resulted in the ban of shipping conferences from the EU trades in the same year. The ban on liner conferences obliged carriers to seek a new regime to optimize service provision and the lengthy process that resulted in the repeal of the antitrust exemption could have motivate partly the research published up to 2008. This policy change together with the untimely economic downturn that severely affected the sector at the end of 2008 made cooperation through SAs more attractive to most shipping lines. Since 2015, a new wave of Mergers \& Acquisition among carriers took place, together with the entry of the three market leaders into new SAs (Maersk, MSC, and CMA CGM). To our view, this can explain the increasing interest of academic research in these agreements.

The literature analysis led us to the identification of three main research areas, which consist of SAs' formation, SAs' management, and SAs' optimization research. The decision to structure the literature review in these three areas was because this subdivision captures the main research topics on SAs over the last 25 years in an intuitive manner and it comprises also previous categorizations. This structuring can be easily understood by practitioners and provides a comprehensive framework for research. Also, it does not preclude the possibility of diving each research area into more in detail, to account for the more complex and methodologically sophisticated contributions. A few other research areas related to less-frequently researched topics are categorized under the ad hoc research category. In the next three sections, the three main research areas are discussed in more detail (Table 2).

\section{The formation of SAs}

Carriers, before entering into an SA agreement, need to define their expectations, requirements, and expected benefits from joining (Agarwal and Ergun 2010). The academic research in the area of SA formation has therefore attracted some attention and has focused on incentives to collaborate and on partner selection (Midoro and Pitto 2000; Evangelista and Morvillo 2000; Mitsuhashi and Greve 2009; Ryoo and Thanopoulou 1999; Borch and Solesvik 2016).

\subsection{The incentives for collaboration}

The incentives for collaboration within an SA can be summarized into five categories (Song and Panayides, 2002), mostly financial, economic, strategic, marketing, 


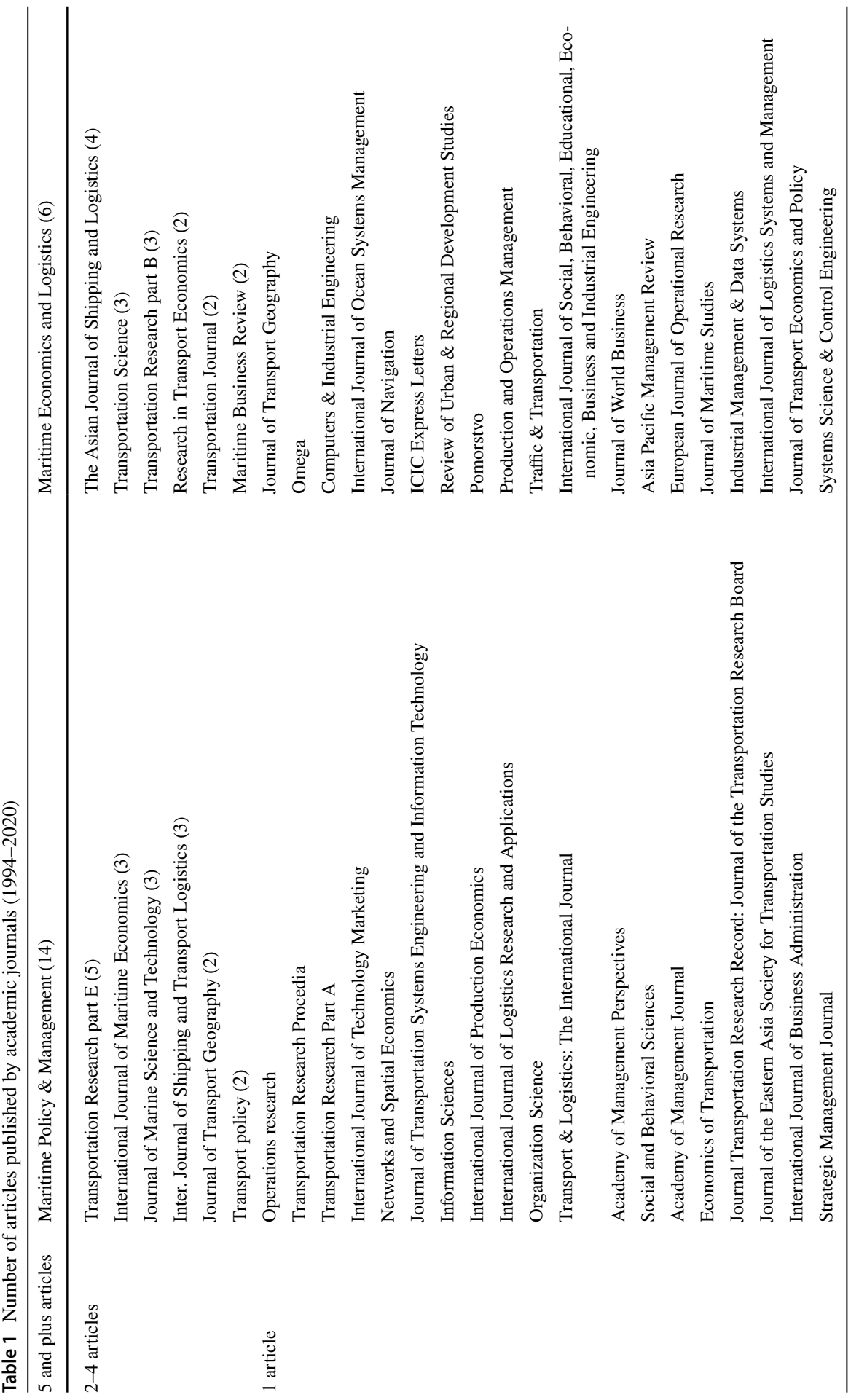

称。 
and operational. In a more recent contribution, based on a survey with executives, Huang and Yoshida (2013) identify eight areas, ranging across finance, economics, strategic management, global supply chains, customer service, market structure, uniqueness, and mergers \& acquisitions. We updated the initial structure of Song and Panayides (2002) with more recent works and reviewed their initial categorization to identify new literature gaps. Our analysis of existing literature is summarized in Table 3, which groups incentives into five generic categories (financial, marketing, and customer support, operational, strategic, and managerial incentives) and 13 sub-categories.

Collaborating within SAs allows for combining cargo on the same route enabling economies of scale for carriers, as operating costs per unit (TEU) decline when larger container vessels are deployed. The benefits are related to bunker costs, crew costs, maintenance, lubricants, etc., as total costs increase less than proportionally to the size of the vessel. As a result, the cost of transporting one TEU is reduced in larger vessels as long as high capacity utilization rates are maintained at least on the head haul.

SAs also generate economies of scope for their members by enabling them to increase their market coverage and connecting services with cross-ocean and feeder routes (Thanopoulou et al. 1999; Mitsuhashi and Greve 2009; Panayides and Wiedmer 2011; Caschili et al. 2014; Cruijssen et al. 2007). Carriers, by means of SAs, have the opportunity of expanding their service networks via dovetailing the operational service routes of each other. Transshipment ports play an important role in this respect (Agarwal and Ergun 2010). For example, as Fig. 3 illustrates, where Carrier 1 initially operates between ports A and B, Carrier 2 between ports B and C, and Carrier 3 between ports $C$ and $D$, sharing services within an SA gives the individual carrier the possibility to expand their service network from port A to port D, without the need for substantial additional investment.

As shown in Fig. 3, carriers, by forming SAs, not only expand their service network but also by having access to a larger number of containerships, can increase the frequency of their services. More frequency and a wider range of service coverage translate to higher service quality, enabled by SAs.

Optimizing capacity utilization is another incentive for carriers to join an SA. Knowledge of aggregate demand along a trade corridor, and the pursuant joint planning of capacity, reduce the number of vessels needed to be deployed by each individual alliance member and, consequently, the corresponding costs (Cruijssen et al. 2007). In the event of collaboration between two carriers, combining cargo allows them to rationalize the use of vessels on the network, improve ship utilization and reduce port costs by allocating container bays in a predetermined way. When considering that shipping remains a very capital-intensive industry, with, for instance, a newbuilding price for a 13,500-TEU vessel amounting to 116 million US dollars in 2019 (Clarkson Research 2020), pooling cargo was for small and medium-size carriers the only way to survive in the race of investment in larger ships, before many of them were bought out by larger players. An interesting tendency is that this initial motivation for joining a global SA has lost relevance over time, as carriers consolidate and alliance membership requires the ability to provide enough capacity. At the time of writing, none of the current three SAs has a member with less than $2.9 \%$ of 


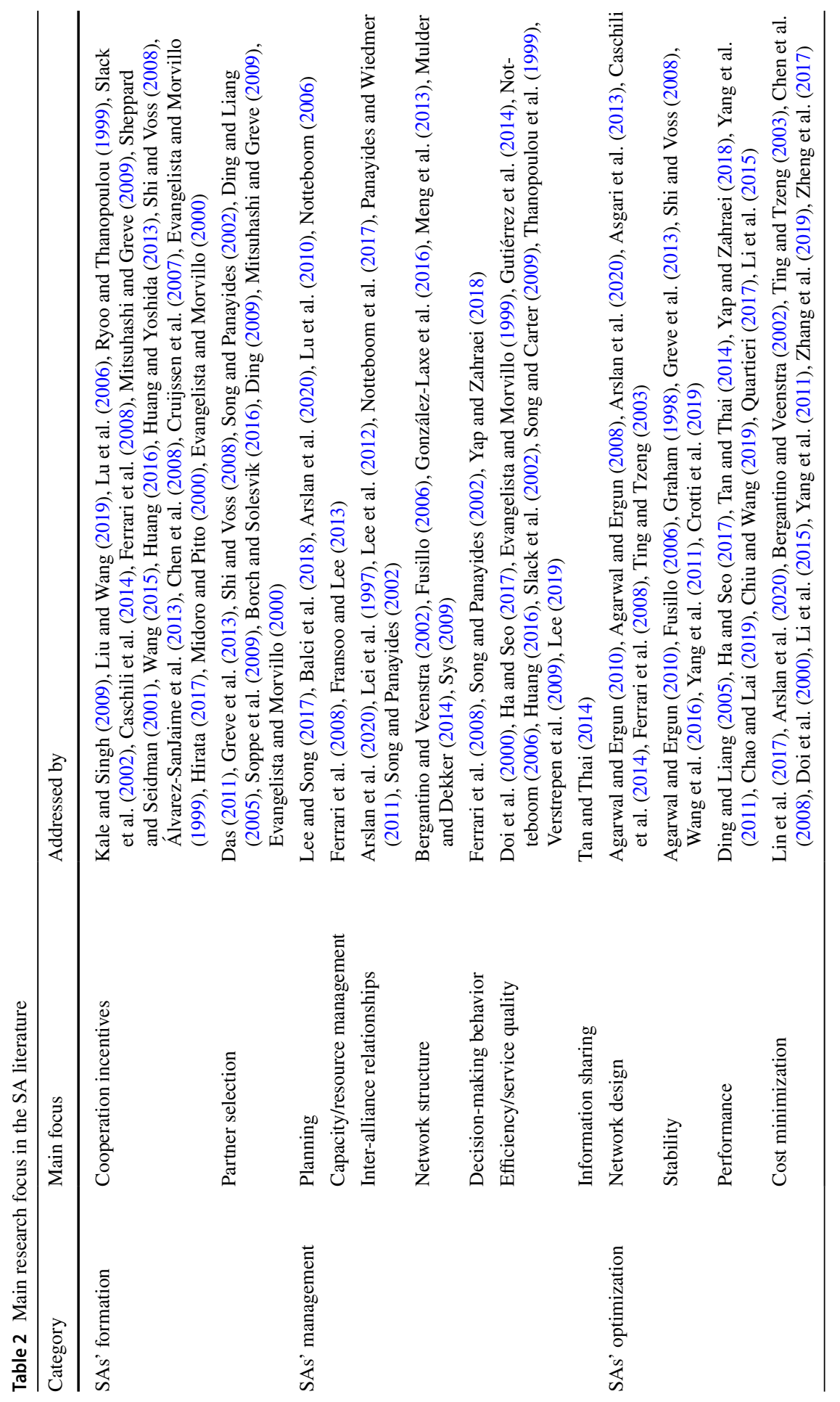

然 


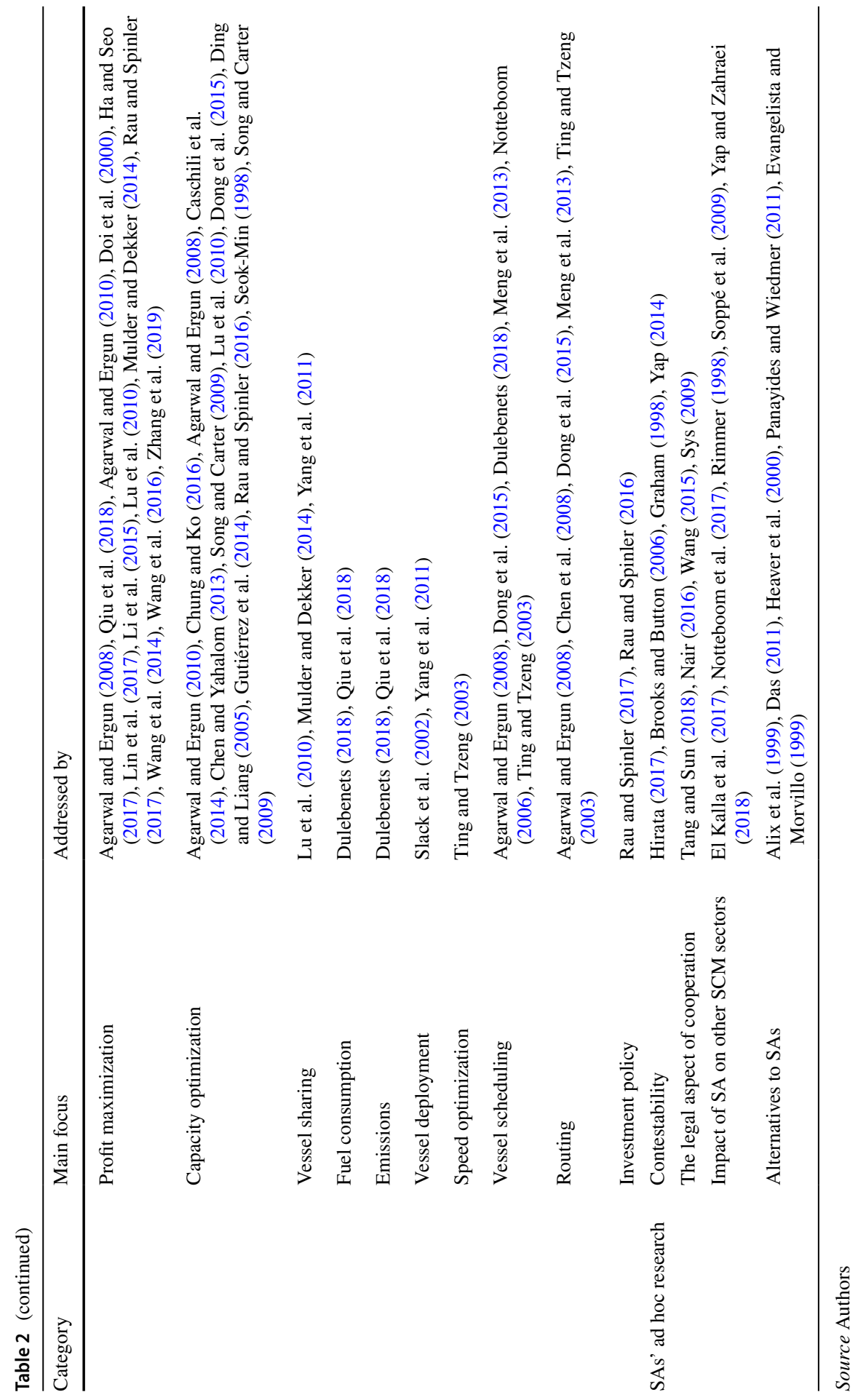


Table 3 The main incentives for joining SAs

\begin{tabular}{|c|c|c|}
\hline Categories & Incentives & References \\
\hline \multirow[t]{3}{*}{ Financial } & Economies of scale & $\begin{array}{l}\text { Mitsuhashi and Greve (2009), Panayides and Wied- } \\
\text { mer (2011), Caschili et al. (2014), Panayides and } \\
\text { Cullinane (2002), Cruijssen et al. (2007), Ryoo } \\
\text { and Thanopoulou (1999) }\end{array}$ \\
\hline & Economies of scope & $\begin{array}{l}\text { Caschili et al. (2014), Panayides and Wiedmer } \\
\text { (2011), Midoro and Pitto (2000), Verstrepen } \\
\text { et al. (2009), Evangelista and Morvillo (1999), } \\
\text { González-Laxe et al. (2016) }\end{array}$ \\
\hline & $\begin{array}{l}\text { Reduced capital investment on } \\
\text { equipment and } \\
\text { container ships }\end{array}$ & $\begin{array}{l}\text { Panayides and Wiedmer (2011), Agarwal and Ergun } \\
\text { (2010), Ryoo and Thanopoulou (1999), Panayides } \\
\text { and Cullinane (2002) }\end{array}$ \\
\hline \multirow[t]{3}{*}{$\begin{array}{l}\text { Marketing \& } \\
\text { Customer } \\
\text { Support }\end{array}$} & Higher frequency of services & $\begin{array}{l}\text { Thanopoulou et al. (1999), Caschili et al. (2014), } \\
\text { Panayides and Wiedmer (2011), Slack et al. } \\
\text { (2002), Verstrepen et al. (2009) }\end{array}$ \\
\hline & Expansion of the network coverage & $\begin{array}{l}\text { Caschili et al. (2014), Panayides and Wiedmer } \\
\text { (2011), Ryoo and Thanopoulou (1999) }\end{array}$ \\
\hline & Stabilize freight rate & Ryoo and Thanopoulou (1999) \\
\hline \multirow[t]{5}{*}{ Operational } & $\begin{array}{l}\text { Reducing the operational risk } \\
\text { (sharing the risk) }\end{array}$ & $\begin{array}{l}\text { Caschili et al. (2014), Panayides and Wiedmer } \\
\text { (2011), }\end{array}$ \\
\hline & $\begin{array}{l}\text { Increase the utilization of container } \\
\text { boxes }\end{array}$ & Ryoo and Thanopoulou (1999) \\
\hline & Rationalize capacity & Panayides and Wiedmer (2011) \\
\hline & $\begin{array}{l}\text { Provide total container logistics } \\
\text { service }\end{array}$ & Ryoo and Thanopoulou (1999) \\
\hline & Maximize operational synergy & \\
\hline \multirow[t]{3}{*}{ Tactical } & Provide more frequent sailings & Ryoo and Thanopoulou (1999) \\
\hline & Rationalize service routes & \\
\hline & Provide intermodal service & \\
\hline \multirow[t]{7}{*}{ Strategic } & Achieve competitive advantages & $\begin{array}{l}\text { Panayides and Wiedmer (2011), Yap and Zahraei } \\
\text { (2018), Ryoo and Thanopoulou (1999) }\end{array}$ \\
\hline & Faster entry to new trade routes & Ryoo and Thanopoulou (1999) \\
\hline & Limit external competition & \\
\hline & Market power & Panayides and Wiedmer (2011), Heaver et al. (2000) \\
\hline & $\begin{array}{l}\text { Develop a liner service for specific } \\
\text { market niches }\end{array}$ & Ryoo and Thanopoulou (1999) \\
\hline & New market entry and market share & $\begin{array}{l}\text { Caschili et al. (2014), Panayides and Wiedmer } \\
\text { (2011), Ryoo and Thanopoulou (1999) }\end{array}$ \\
\hline & $\begin{array}{l}\text { Conform to the shipping policy of the } \\
\text { national and foreign government }\end{array}$ & Ryoo and Thanopoulou (1999) \\
\hline \multirow[t]{4}{*}{ Managerial } & Knowledge sharing & Caschili et al. (2014), Tan and Thai (2014) \\
\hline & $\begin{array}{l}\text { Better utilization of existing infra- } \\
\text { structure and assets }\end{array}$ & Verstrepen et al. (2009) \\
\hline & $\begin{array}{l}\text { Gain access to general management } \\
\text { skills }\end{array}$ & Ryoo and Thanopoulou (1999) \\
\hline & $\begin{array}{l}\text { Vessel planning and coordination on } \\
\text { a global scale }\end{array}$ & Panayides and Wiedmer (2011) \\
\hline
\end{tabular}

Source Authors

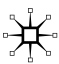




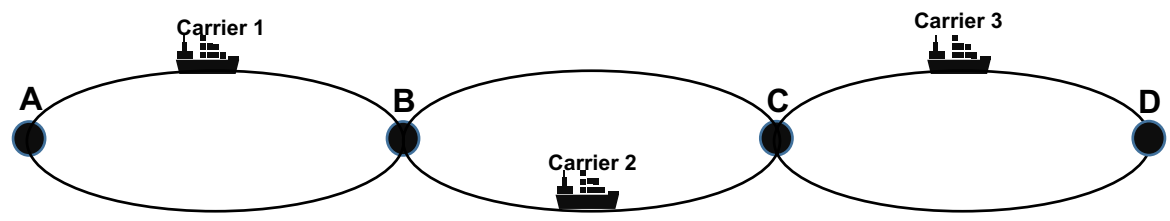

Fig. 3 Network expansion through SAs. Source Authors

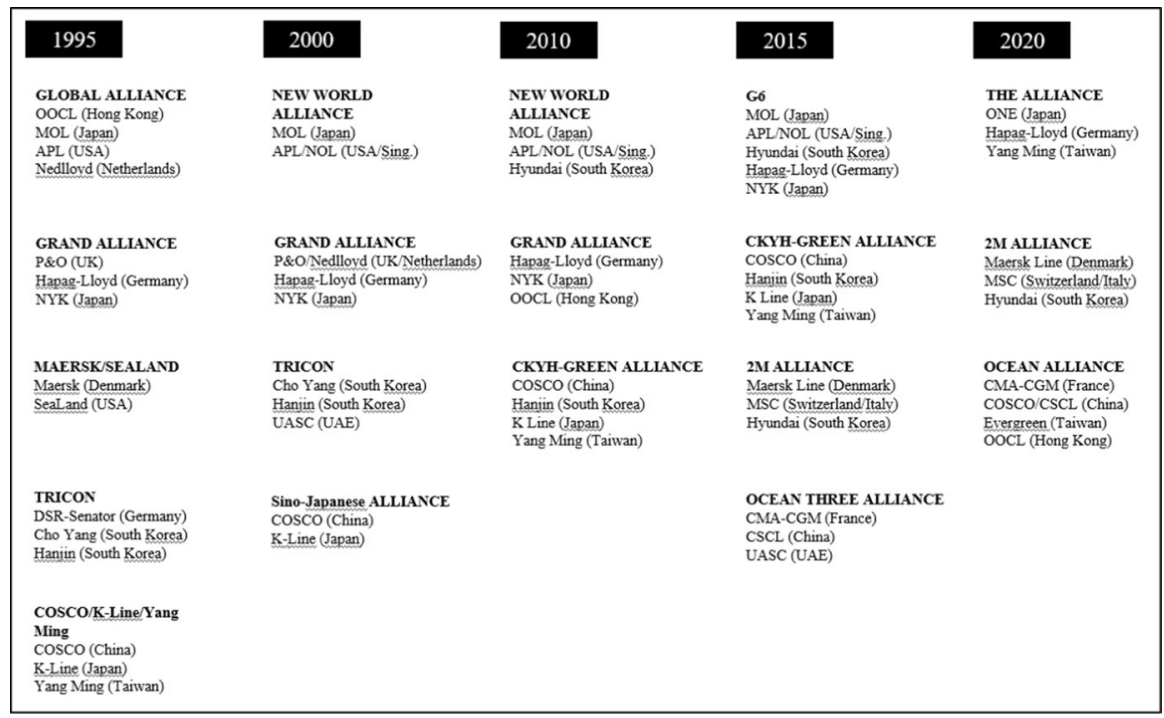

Fig. 4 Main changes in SAs composition since 1995. Source Authors

global market share, reflecting how small- and even medium-sized carriers have all been bought out by larger players (Alphaliner, 2020). Joining SAs also reduces operational risks such as cargo loss or damage, piracy, terrorist attacks, or risks related to the unreliability of service schedules. Sharing the risks of operation decreases the negative consequences of these risk factors for each carrier and makes operations more resilient.

\subsection{Partner selection}

An important characteristic of SAs is their instability (Fig. 4) involving frequent reshufflings, which have negatively affected both the performance of SAs and the quality of their services to shippers (Rau and Spinler 2017; Midoro and Pitto 2000). Selecting the right partner is therefore another important research question in the literature (Das 2011; Shi and Voss 2008; Song and Panayides 2002). Carriers need to assess the strategic and operational capabilities of competitors before entering into an SA agreement (e.g., Lee 2019; Song and Panayides 2002). 
Table 4 SA's partner selection criteria

\begin{tabular}{|c|c|}
\hline Main criteria & Sub-criteria \\
\hline Complementarity & $\begin{array}{l}\text { Wider and deeper geographical scope, managerial capabili- } \\
\text { ties of lines, service channels, or places, increase in the } \\
\text { frequency of service, net handling performance at the } \\
\text { container terminal, increase in local or regional market } \\
\text { access }\end{array}$ \\
\hline Deeper contents and forms of collaboration & $\begin{array}{l}\text { Ships fitting with the cooperative routes, using dedicated } \\
\text { terminals together, extending interests in the integrated } \\
\text { hinterland transport service, business-supported activities, } \\
\text { co-ordination of sales and marketing activities }\end{array}$ \\
\hline Compatibility & $\begin{array}{l}\text { Cultures, communication, and coordination, symmetry in } \\
\text { organizational size, trust and commitment, compatibility } \\
\text { in strategic goals, conflicts management techniques }\end{array}$ \\
\hline Financial health & $\begin{array}{l}\text { Return on stockholders' equity, profit margin, return on } \\
\text { assets, return on long-term investment }\end{array}$ \\
\hline Adequate physical facilities and equipment & $\begin{array}{l}\text { Handling equipment, terminal hectares, using containers } \\
\text { and chassis together, information-sharing system }\end{array}$ \\
\hline Intangible assets & $\begin{array}{l}\text { Brand and firm reputation, experience sharing, good human } \\
\text { resources }\end{array}$ \\
\hline Market knowledge access & $\begin{array}{l}\text { Understanding competitors and customers, experience with } \\
\text { government, regulations, unique competencies, capabili- } \\
\text { ties to provide total quality service }\end{array}$ \\
\hline
\end{tabular}

Source Derived from Ding and Liang (2005)

Table 4 summarizes the seven main criteria and 44 sub-criteria for the selection of the most appropriate strategic partners identified by Ding and Liang (2005).

Among these criteria, two are essential for partner selection. The first regards market complementarity, which means the potential to strengthen each other. This can offer various benefits, such as enhancing the geographical coverage of the SA members, improving service frequency, or sharing operational knowledge. Market complementarity depends on ship specifications, primarily ship size, the number of vessels available to each carrier, and available terminal capacity in the various ports of the network. Market complementarity has a direct impact on economies of scope and, in particular, potentially grants access to new markets (Agarwal and Ergun 2010; Kale and Singh 2009; Mitsuhashi and Greve 2009), which was one of the primary drivers of SAs in the 1990s. As illustrated in Fig. 4, SAs were initially composed of carriers of different nationalities, with their specific market knowledge and access.

Partner selection can also be based on the ability of the partners to bring new technical/operational competencies concerning, for example, energy reduction technologies, ship management, hinterland transportation, or cargo packaging and warehousing. For example, in July 2019, "THE Alliance" officially announced an expansion to include the Korean Shipping Company, Hyundai Merchant Marine (HMM). The main reason for this enlargement, as announced by the CEO of Hapag-Lloyd, was "HMM is a great fit for THE Alliance as they will provide a number of new and modern vessels, which will help us to deliver better quality and be more efficient and 
it will help us also to further reduce our emissions" (Rolf Habben Jansen as reported in Hapag-Lloyd 2019).

The second criterion is compatibility, and it refers to the degree of similarity between potential partners such as working styles and cultures (Kale and Singh 2009; Haralambides 1996), trust and commitment, strategic fit, and stable financial position (Solesvik and Westhead 2010; Kale and Singh 2009). Das (2011) carried out an empirical investigation to identify and examine eight effective factors of carriers' strategic choice between partnerships and acquisitions. In this study, the authors conclude that the following four factors have a positive impact on choosing 'acquisition' as a strategy: redundant resources, the intensity of competition among carriers, the home region of a shipping company, and prior acquisition experience of the firm. However, prior partnership experience increases the probability of 'partnership', while the level of synergy and the degree of market uncertainty have a neutral impact on selecting partnership over acquisition and vice versa.

\section{The management of SAs}

The second main research area for SAs is management. In practice, a large variety of management activities within SAs are performed by collaborative committees (Tan and Thai 2014). Each committee is responsible for decision-making and for carrying out a specific part of SA activities. Such a committee typically comprises one representative from each SA member. According to Tan and Thai (2014), the principal committees, consisting of the CEOs of the SA members, are responsible for making decisions such as the scope of geographical coverage and the volume of pooled assets by each member. The steering committees, including senior and middle managers as members, are responsible for executing decisions and directions made by the principal committees, such as service loop deployments and service timings and how vessels are allocated to each shared route. Finally, it is up to the support committees to plan for the daily operations of the alliance,, which involves several tasks like providing vessel berthing windows, vessel schedules, legal agreements, etc. In this section, we present the results of our review on research that has concentrated on the above managerial issues.

Lu et al. (2006) interviewed experts who have participated in the definition of the Operating Cost Contribution (OCC) of the no longer-existing CKYH alliance, which had consisted of Cosco Container Lines, "K" Line, Yang Ming Line, Hanjin Shipping and later Evergreen, to identify and prioritize the factors that determine the success of a SA. In this study, the authors conclude with a list of SA success factors, specifically: "Mutual trust between all partners, the number \& size of partners, partner compatibility, a reasonable and practicable cooperating rule for following up, continuous mutual commitment of facilities, mutual agreement on co-operation objectives, good understanding by all parties of competition and marketplace, compatible decision-making processes, open communication between the parties, good relations between the employees of the partner, and continuous CEO direction and involvement" (p. 208). Among all, the level of mutual trust between members is the most important success factor for a SA. Tan and Thai (2014) stress that the longer 
the collaboration among SA members, the higher the level of mutual trust that can be created among them (in line with Solesvik and Westhead 2010; Song and Panayides 2002).

Exchanging operational information among SA members is the next important management activity. Based on the SA agreements (Ocean alliance FMC agreement 2019, p. 5), carriers are entitled to obtain, maintain, and exchange among themselves operational knowledge and information such as statistics, studies, and consultancy reports related to their operations on different trade lanes. This information pertains to different operational aspects like forecasts of vessel utilization, length of port/terminal stays, productivity, schedule performance, and third-party costs like terminal and bunker costs. Sharing this information helps carriers to jointly make projections and plans associated with their vessel capacity and service structure and ensure the smooth running of operations (Zaheer and Venkatraman 1995). However, research on the aforementioned areas within SAs among carriers remains limited.

Tan and Thai (2014) performed several face-to-face interviews with senior management executives of liner shipping operators and concluded that there are formal and informal knowledge-sharing mechanisms within SAs. Face-to-face meetings, video or teleconferencing, e-mails, and phone calls are the main formal knowledgesharing mechanisms, while dinners, drinks, and coffee sessions, among other casual exchanges, are introduced as the informal ways of information sharing among SA's members. This study also reveals that knowledge sharing among SA partners is limited to operational information, as sharing market-related information, such as freight rates and the list of customers, is strictly prohibited by antitrust laws. Moreover, the members are willing to share operational information to improve the benefit of their SA.

The stability of SAs among liner shipping companies is often defended as a consequence of successful management of these agreements. Stability is necessary for both alliance parties and shippers to establish long-term trading relationships (Brooks 2004) to ensure stability of freight rates and services (Fusillo 2006) and more reliable schedules (Graham 1998). The unstable structure of SA membership, as depicted in Fig. 4, is rooted instead in mergers and acquisitions between carriers inside and outside their SA, reshufflings of SA membership, to be able to compete with large carriers and other SAs. The main determinants of SA's instability are categorized in Table 5.

Additionally, Fig. 5 shows how many times each factor is mentioned in the literature as an important factor of the instability of SAs.

According to Rau and Spinler (2017) intra-alliance competition is the main factor of instability, as carriers compete fiercely to increase their market share. Midoro and Pitto (2000) also highlight organizational complexity as a determinant of SA instability. The same authors explain that, with the increasing success of an SA, the inclination of its members to increase the volume of their own pooled resources will also increase in order to earn more benefits out of their successful SA. This situation leads to an unavoidable increase in the complexity of tasks required to manage the higher level of participation by SA members.

The number of SA's members, their role in the alliance, and the level of mutual trust among members affect organizational complexity. More members in the 
Table 5 The main determinants of SAs instability

\begin{tabular}{|c|c|c|}
\hline Category & Instability determinant & References \\
\hline \multirow[t]{3}{*}{$\begin{array}{l}\text { Partner char- } \\
\text { acteristics }\end{array}$} & $\begin{array}{l}\text { Insufficient level of partner } \\
\text { complementarity }\end{array}$ & Agarwal and Ergun (2010) \\
\hline & Inappropriate number of partners & Song and Panayides (2002), Midoro and Pitto (2000) \\
\hline & Structure of member's demands & Yang et al. (2011), Slack et al. (2002) \\
\hline \multirow{4}{*}{$\begin{array}{l}\text { Partner rela- } \\
\text { tionships }\end{array}$} & Intra-alliance competition & Midoro and Pitto (2000), Rau and Spinler (2017) \\
\hline & Partner commitment & Yang et al. (2011) \\
\hline & The level of mutual trust & $\begin{array}{l}\text { Song and Panayides (2002), Solesvik and Westhead } \\
\text { (2010), Midoro and Pitto (2000) }\end{array}$ \\
\hline & The nature of partner roles & Song and Panayides (2002), Midoro and Pitto (2000) \\
\hline \multirow{2}{*}{$\begin{array}{l}\text { Complex } \\
\text { structures of } \\
\text { collabora- } \\
\text { tion }\end{array}$} & Cooperation cost complexity & Rau and Spinler (2017) \\
\hline & Organizational complexity & Midoro and Pitto (2000) \\
\hline \multirow[t]{3}{*}{ Other factors } & Outside options & Greve et al. (2013) \\
\hline & $\begin{array}{l}\text { Coordination and direct access } \\
\text { costs }\end{array}$ & Bergantino and Veenstra (2002) \\
\hline & Freight rate volatility & Rau and Spinler (2017) \\
\hline
\end{tabular}

Source Authors

Number of articles emphasizing stability/instability determinants of SAs

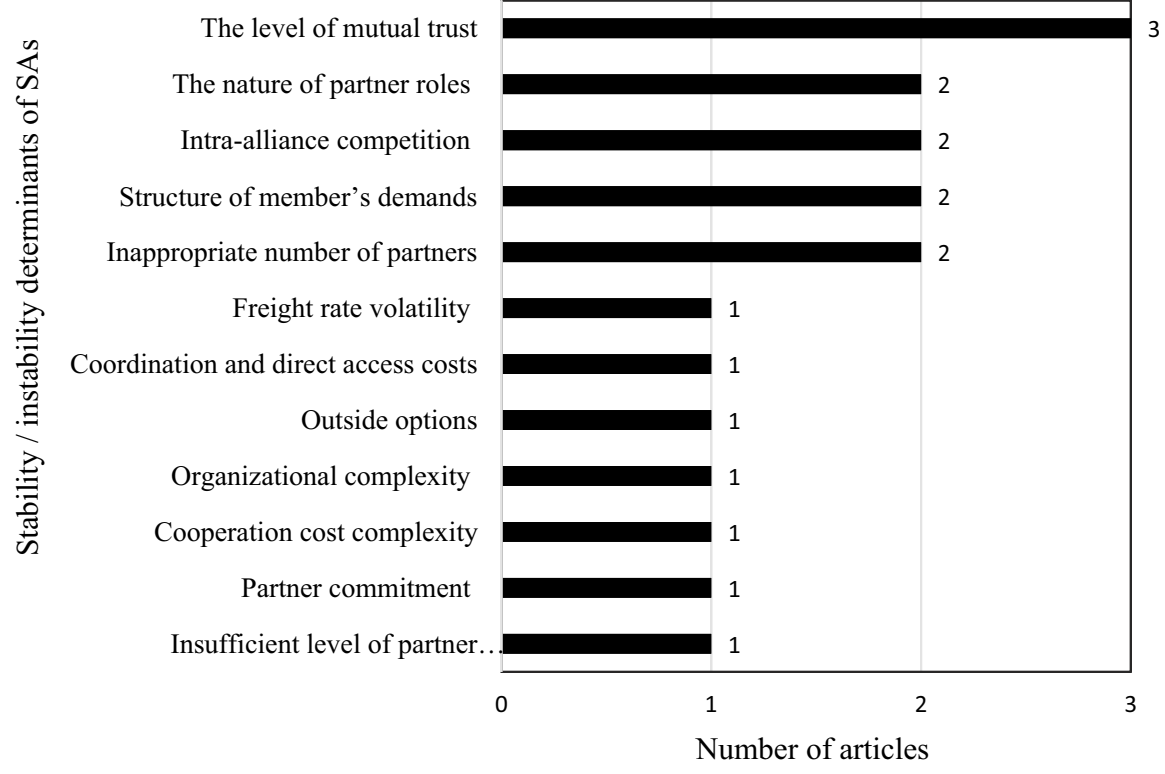

Fig. 5 Instability determinants of SAs. Source Authors 
alliance turn the management of these agreements into a more time-consuming process as each member needs to be involved in each decision made in the alliance. However, a fair allocation of roles and contributions of each member in the SA decision-making process facilitates the management of a larger number of members in a SA (Song and Panayides 2002; Midoro and Pitto 2000). Further complexity is related to the management costs that grow as the number of members grows (Killing 1988). This complexity, if not managed properly, leads to the dissatisfaction of some members and may result in them leaving the collaboration.

Greve et al. (2013) study the impact of collaboration opportunities offered by container carriers who are operating outside the alliance on the probability of withdrawal of members from an existing SA. They show that, even when an alliance can be considered as successful in terms of stability in its composition, members are willing to leave the SA to opportunistically pursue collaboration with other carriers outside the alliance with which they perceive to have a higher market complementarity.

\section{The optimization of SAs}

Optimizing SAs is the third major area of research, dealing with a wide range of strategic, tactical, and operational challenges. Among them, maximizing shared or individual profits and enhancing the quality of services, i.e., the frequency and geographical coverage, and improving the stability of SAs, are critical. To tackle these challenges, researchers have addressed several relevant problems, including SA network design, capacity optimization, vessel scheduling, service routing, vessel deployment, partner selection, cost minimization, and revenue maximization. Various methods have been used to that effect, such as linear and non-linear programming, game theory, dynamic programming, stochastic programming, etc. Table 6 summarizes these studies and lists the most frequent optimization problems and the approaches used to find solutions.

Apart from the studies reviewed in Sect. 4 (and reported in Table 5) that concentrate on the main determinants of SA instability, there are also a few quantitative studies that try to enhance the stability of SA collaborations. The typical approach used in these studies is to formulate a collaborative setting in which all SA parties can obtain fair payoffs in proportion to their contributions to the alliance. To this end, cooperative game theory (CGT) and, in particular, core theory, has been the approach employed most frequently in the literature. Given the importance of CGT and the theory of the core for SA, a brief explanation of these two approaches and how they are related to SA collaborations is provided below.

CGT refers to a large family of games in which the players are allowed to form coalitions to maximize their overall utility. A cooperative game consists of a finite set of $N=\{1,2, \ldots, n\}$ players, which is also called the grand coalition of the players, a characteristic function, $C F: 2^{n} \rightarrow \mathbb{R}$, that assigns a set of outcomes $O(M)$ to any possible subset (coalition) of $M \subset N$, and a set of payoffs vector $V(M)$ corresponding to the outcomes. The payoff vector $v$ determines the payoffs of each player 
Table 6 SAs optimization-related papers

\begin{tabular}{|c|c|c|}
\hline Paper & Problem and major concentrations & Approach \\
\hline Arslan et al. (2020) & Network design & Heuristic algorithms \\
\hline Crotti et al. (2019) & Stability & Non-cooperative game theory \\
\hline Zhang et al. (2019) & $\begin{array}{l}\text { Profit maximization, empty } \\
\text { containers } \\
\text { repositioning }\end{array}$ & Linear programming \\
\hline Dulebenets (2018) & $\begin{array}{l}\text { Fuel consumption, vessel schedul- } \\
\text { ing }\end{array}$ & Non-linear programming \\
\hline Lin et al. (2017) & Profit maximization & $\begin{array}{l}\text { Cooperative game theory, linear program- } \\
\text { ming, heuristic algorithms }\end{array}$ \\
\hline Zheng et al. (2017) & Cost allocation & Duality, inverse optimization, Shapley value \\
\hline Chung and Ko (2016) & $\begin{array}{l}\text { Profit maximization, slot } \\
\text { exchange }\end{array}$ & $\begin{array}{l}\text { Mixed-integer linear programming, min- } \\
\text { sum method }\end{array}$ \\
\hline $\begin{array}{l}\text { Rau and Spinler } \\
\text { (2016) }\end{array}$ & $\begin{array}{l}\text { Investment policy, capacity } \\
\text { optimization }\end{array}$ & $\begin{array}{l}\text { Real options analysis, individual and collec- } \\
\text { tive discounted cash flow }\end{array}$ \\
\hline Wang et al. (2016) & Stability, profit maximization & Cooperative game theory \\
\hline $\begin{array}{l}\text { Angeloudis et al. } \\
\text { (2015) }\end{array}$ & Network design & $\begin{array}{l}\text { Non-cooperative game theory, backward } \\
\text { induction }\end{array}$ \\
\hline Dong et al. (2015) & Capacity optimization, routing & Stochastic programming \\
\hline Zheng et al. (2015) & $\begin{array}{l}\text { Network design, cost minimiza- } \\
\text { tion, capacity exchange costs } \\
\text { (side payments) }\end{array}$ & $\begin{array}{l}\text { Mixed-integer linear programming, inverse } \\
\text { optimization }\end{array}$ \\
\hline Gutiérrez et al. (2014) & Efficiency evaluation & Bootstrap DEA approach \\
\hline Parola et al. (2014) & $\begin{array}{l}\text { A propensity to cooperate, the } \\
\text { geographic extent and leverag- } \\
\text { ing effect }\end{array}$ & Network and OLS regression analysis \\
\hline $\begin{array}{l}\text { Álvarez-SanJaime } \\
\text { et al. (2013) }\end{array}$ & Profit maximization & Cooperative game theory \\
\hline Asgari et al. (2013) & $\begin{array}{l}\text { Network design, cost minimiza- } \\
\text { tion }\end{array}$ & $\begin{array}{l}\text { Cooperative game theory, linear program- } \\
\text { ming }\end{array}$ \\
\hline $\begin{array}{l}\text { Chen and Yahalom } \\
\text { (2013) }\end{array}$ & Capacity optimization & Linear programming \\
\hline Greve et al. (2013) & Stability & Matching theory \\
\hline Yang et al. (2011) & Stability, economic performance & Cooperative game theory \\
\hline Yang et al. (2011) & Economic performance & Cooperative game theory \\
\hline $\begin{array}{l}\text { Agarwal and Ergun } \\
(2010)\end{array}$ & $\begin{array}{l}\text { Network design, capacity opti- } \\
\text { mization, profit maximization, } \\
\text { stability, capacity exchange } \\
\text { costs (side payments) }\end{array}$ & $\begin{array}{l}\text { Cooperative game theory, rationality-based } \\
\text { approach, inverse optimization }\end{array}$ \\
\hline Lu et al. (2010) & $\begin{array}{l}\text { Capacity optimization, vessel } \\
\text { sharing }\end{array}$ & Non-linear programming \\
\hline $\begin{array}{l}\text { Song and Carter } \\
\text { (2009) }\end{array}$ & Capacity optimization & Inverse optimization \\
\hline $\begin{array}{l}\text { Agarwal and Ergun } \\
\text { (2008) }\end{array}$ & $\begin{array}{l}\text { Network design, capacity opti- } \\
\text { mization, vessel scheduling, } \\
\text { routing }\end{array}$ & Linear programming \\
\hline Shi and Voss (2008) & Stability, partner selection & Non-cooperative game theory \\
\hline
\end{tabular}


Table 6 (Continued)

\begin{tabular}{lll}
\hline Paper & Problem and major concentrations & Approach \\
\hline $\begin{array}{l}\text { Ding and Liang } \\
\text { (2005) }\end{array}$ & $\begin{array}{c}\text { Capacity optimization, partner } \\
\text { selection }\end{array}$ & $\begin{array}{c}\text { FMCDM (Fuzzy multiple criteria decision- } \\
\text { making) }\end{array}$ \\
$\begin{array}{c}\text { Ting and Tzeng } \\
(2003)\end{array}$ & $\begin{array}{c}\text { Vessel scheduling, speed optimi- } \\
\text { Dynamic programming }\end{array}$ & \\
\hline
\end{tabular}

Source Authors

if the outcome $o$ is realized. In cooperative games, the central problem is how these payoffs should be fairly distributed among the players in proportion to their contributions to the coalition. The notion of the core is one of the most prominent and widely accepted one, in terms of fair allocation of costs and benefits in CGT, and it is similar to a Nash equilibrium in non-cooperative game theory (Agarwal and Ergun 2010). The core of a cooperative game is the set of payoffs where no subcoalitions of the grand coalition $N$ can generate higher payoffs. These approaches fit well with the attributes of SA collaboration agreements and hence their frequency in the SAs' literature.

Song and Panayides (2002), for the first time and by means of a simple problem including three ports and three carriers, explain how core theory can be applied to SAs. The concept of the core had already been applied by Sjostrom in a series of papers (e.g., Sjostrom 1989, 1993) looking at the impact of collaborative agreements, and especially conferences, in liner shipping. Agarwal and Ergun (2010) design a cooperative game cost distribution mechanism in a way that all members are motivated to act in the best interest of the SA while maximizing their own benefits. In this paper, the core of the cooperative game is defined as the set of strategies for which demand fulfilment for each player is maximized, the number of idle ships for each player is minimized, and the pooled capacity in the alliance is jointly maximized. The authors show that such optimal strategies exist (i.e., the core is not empty) by simulating 50 randomly generated instances for each class of parameters and showing that more than $95 \%$ of the test classes result in a non-empty core.

Dong et al. (2001) apply core theory from a cost perspective, in order to study the economic performance and stability of liner shipping alliances, where the goal is to provide a stable condition (the core) in which each party has a rational share ratio of payoffs. Then, the authors study different situations in which the core is empty and analyze the main reasons for the emptiness of the core.

Yang et al. (2011) employ core theory to study how the increase in ship size plays on the performance and stability of SAs. By modeling the cost functions of the members of the SA, the authors test under what circumstances individual and collective rationality conditions (i.e., existence of a non-empty core) are met. Collective rationality means that forming an SA should generate profits for all members and individual rationality means that no member that adopts a strategy that is included in the core can obtain higher profits (that is how the payoffs are defined in that game) by deviating from the current arrangement and forming other coalitions. The stability of the SA is then assessed based on these two conditions via a sample numerical case study. In this, the authors conclude that although forming SAs will 
not prevent an empty core, it can be shown that this can improve the performance and stability of the SA to some degree.

Wang et al. (2016) investigate how in theory profit-sharing mechanisms could benefit the stability of SAs. The authors illustrate how, in the case of the G6 $6^{2}$ alliance, the capacity of its members had been expanded unequally from 2005 to 2015 , in practice resulting in different benefits from alliance membership. Then, they used this example to point to how in theory a fairer distribution mechanism based on a modified Shapley value would provide a better payoffs distribution that allocates payoffs amongst dominant and non-dominant players.

Crotti et al. (2019) apply non-cooperative game theory to analyze the impact of the vertical integration of SA members and terminal operators on the stability of SAs. This study reveals that when the SA agreements are extended to terminal operations and all members benefit from this vertical integration, the alliance's stability is enhanced as sunk costs from leaving the SA would increase. However, if the terminal integration concerns some members only, other members are likely to experience higher terminal tariffs and will leave the SA.

There are few studies that attempt to design the network of an SA. Most of these studies incorporate linear (integer) programming approaches to design the network. Agarwal and Ergun (2010) based on Agarwal and Ergun (2008), suggest a multistage optimization approach to manage the interactions among alliance members. In their study, the authors apply mixed-integer programming (MIP) to design the network of an SA. The authors use the concept of mechanism design derived from CGT and suggest a mechanism to motivate the alliance partners to pursue an optimal strategy for the SA while maximizing their profit. A similar model by Agarwal and Ergun (2008) also accounts for different sizes and characteristics of the vessels and container trans-shipment operations.

Zheng et al. (2015) use an integrated mixed-integer linear programming model and include network design, routing, and capacity exchange problems. They also incorporate a demand variable and modify the mechanism suggested by Agarwal and Ergun (2010) to calculate the capacity exchange costs by applying the inverse optimization technique. Note that in the model suggested by Zheng et al. (2015), the optimal set of service routes is assumed to be given, and transportation costs are not considered.

According to the reviewed optimization papers in this section, presented in Table 6, a wide range of optimization problems and quantitative solution approaches have been utilized in the literature to model SA collaborations. In this regard, our review revealed that the majority of research in this area is focused on enhancing the profit of SA members (Álvarez-SanJaime et al. 2013; Wang et al. 2016; Lin et al. 2017; Zhang et al. 2019) and capacity optimization (Song and Carter 2009; Lu et al. 2010; Chen and Yahalom 2013; Dong et al. 2015). As for the solution approaches, cooperative game theory and linear programming have been employed the most.

As shown in Table 2, there are additional areas of research that do not easily fit in the three groupings proposed in this paper. These areas refer to research questions

\footnotetext{
${ }^{2}$ The G6 alliance comprised of APL, Hapag-Lloyd, Hyundai Merchant Marine, MOL, NYK Line and Orient Overseas Container Line.
} 
that border with other disciplines, such as industrial organization, antitrust law, and port management, to which SAs offer interesting applications. In particular, the theory of contestable markets has been applied to explain the current developments of SAs and how market conditions can be explained by barriers to entry in liner shipping, or why a high degree of competition is observed in some routes (e.g., Hirata 2017; Brooks and Button 2006; Graham 1998; Yap 2014) but not in others. This relates also to the analysis of whether the economic rationale for antitrust exemptions granted to liner shipping should remain, in light of the experiences in the USA and Europe (Tang and Sun 2018; Nair 2016). Some authors (e.g., Alix et al. 1999; Wang 2015) investigate alternatives to SAs, finding that the experiences with SAs vis-à-vis other forms of collaboration seem to lead to higher benefits in terms of market stability and welfare. Finally, some research has also dealt with the implications of SAs on terminals and port authorities (e.g., El Kalla et al. 2017; Notteboom et al. 2017; Yap and Zahraei 2018; Heaver et al. 2000) and on global supply chains (Evangelista and Morvillo 1999). The implications of SAs on supply chain management have been studied so far only marginally (Heaver et al. 2000).

\section{Future research and conclusion}

This paper presented a comprehensive literature review related to liner shipping alliances. In total, 85 articles published in peer-review journals between 1994 and 2019 were selected via a systematic approach and categorized into three main areas of research, namely alliance formation, management, and optimization.

The analysis led us to the identification of areas for future research (Table 7). As shown in Table 2, regarding the formation of SAs, considerable attention has been devoted to understanding the incentives of carriers for joining or establishing SAs (Ferrari et al. 2008; Hirata 2017; Liu and Wang 2019) and to partner selection (Evangelista and Morvillo 2000; Ding and Liang 2005; Ding 2009; Soppe et al. 2009). There is, however, less research devoted to understanding the reasons for joining an SA instead of engaging in M\&A. The shift that happened in 2014, when major companies (notably Maersk Line, MSC, and CMA CGM) decided to change their strategy from M\&A to SAs, indicates that SAs have become more attractive than before. In some cases, this choice might be explained by the existence of governmental ownership, preventing M\&As for political reasons. This also relates to the way in which regulators have dealt with SAs and M\&As in the past and how, particularly in the US, in Europe, and today in China. The focus of regulators is an important area for further research.

Even though the main factors determining the selection of SA partners have already been addressed in the literature, there is still limited knowledge on what criteria are used in practice to assess the suitability of a partner to the alliance and how such criteria are measured. The study of partner selection criteria is critical as some of them, like compatibility and financial health, are not easy to measure. It would be also interesting to have more insight into the negotiation process amongst companies, particularly before reaching an agreement (case of failures). Another 
Table 7 Directions for further research

\begin{tabular}{|c|c|c|c|}
\hline Formation of SAs & Management of SAs & Optimization of SAs & Other \\
\hline $\begin{array}{l}\text { Investigating on likely rea- } \\
\text { sons for shifting carriers } \\
\text { from M\&As to SAs }\end{array}$ & $\begin{array}{l}\text { Addressing mechanisms } \\
\text { to monitor shared risks } \\
\text { amongst members }\end{array}$ & $\begin{array}{l}\text { Considering realistic con- } \\
\text { straints such as heteroge- } \\
\text { neity of the pooled fleets, } \\
\text { and fair distribution of } \\
\text { reefer plugs on each } \\
\text { container ship among } \\
\text { members in optimization } \\
\text { models }\end{array}$ & $\begin{array}{l}\text { Empirical } \\
\text { research on } \\
\text { the impact of } \\
\text { SAs on: } \\
\text { The growing } \\
\text { size of con- } \\
\text { tainerships } \\
\text { Other } \\
\text { container } \\
\text { transport } \\
\text { stakeholders }\end{array}$ \\
\hline $\begin{array}{l}\text { Addressing mechanisms } \\
\text { to measure the already } \\
\text { established partner selec- } \\
\text { tion criteria }\end{array}$ & $\begin{array}{l}\text { Study on the additional } \\
\text { benefits of SAs for mem- } \\
\text { bers on a company level }\end{array}$ & $\begin{array}{l}\text { Considering the physical } \\
\text { restrictions of ports such } \\
\text { as tides and port drafts in } \\
\text { SAs operations }\end{array}$ & $\begin{array}{l}\text { Empowering } \\
\text { the econo- } \\
\text { mies of } \\
\text { countries }\end{array}$ \\
\hline $\begin{array}{l}\text { Research on before agree- } \\
\text { ment negotiation process, } \\
\text { in particular, the case of } \\
\text { failures }\end{array}$ & $\begin{array}{l}\text { Addressing a quantita- } \\
\text { tive mechanism to fairly } \\
\text { distribute vessel expenses } \\
\text { among members of SAs }\end{array}$ & $\begin{array}{l}\text { Considering transshipment } \\
\text { costs in optimization } \\
\text { models }\end{array}$ & \\
\hline $\begin{array}{l}\text { The role of new shipping } \\
\text { technologies on partner- } \\
\text { ship structure of SAs }\end{array}$ & $\begin{array}{l}\text { Motivational mechanisms } \\
\text { to encourage SAs' } \\
\text { members to share their } \\
\text { operational information }\end{array}$ & $\begin{array}{l}\text { Fair distribution of loading } \\
\text { and unloading port time } \\
\text { among members }\end{array}$ & \\
\hline
\end{tabular}

Source Authors

interesting research topic is identifying the role of newly emerged shipping technologies on the partnership structure of SAs.

For the management-related aspects of SAs, our review covered subjects such as the success factors of SA collaboration, operational planning, and managing the shared information and knowledge among SA's parties, as well as reviewing SA stability-related literature. In this area, there is still limited knowledge on how to monitor shared risks amongst members, and which benefits can be expected from SAs. In particular, there is no study at a company level to investigate how much additional profit can be expected by operating within vis à vis outside an alliance. Another research topic is related to how vessel expenses can be optimally shared. Most agreements entail that each party is responsible for bearing all the operational expenses for the vessels they operate in the SA. However, as the available capacity on each shared vessel is unequally distributed among parties, the expenses of each vessel need to be fairly shared and reviewed from time to time, or based on a preagreed regular schedule (THE alliance FMC agreement 2019; Ocean alliance FMC agreement 2019).

To share such operating costs, members may agree on an alliance Reference Cost Model (SA RCM). The average of individual cost models of each member is normally used to build the SA RCM. For instance, the 2M and THE Alliance define their RCM per trade lane, whereas The OCEAN alliance specifies it per service (Merk 2018, p. 17). An interesting research area associated with this topic is 
developing mechanisms to encourage the members of a SA to share operational information with other members and finding ways of distributing the shared information in a way that all parties can easily access, although this could be hindered by the need to comply with existing regulation.

For the third category of research, i.e., optimization, we elaborated on the main optimization problems associated with the topic of SAs, and the most widely employed quantitative methods by researchers to deal with these problems. In this area, new directions for further research at the tactical and operational levels could be investigated. At the tactical level, relaxing some constraints (Agarwal and Ergun 2008; Asgari et al. 2013; Zheng et al. 2015) such as the assumption of homogeneous ship fleets for each carrier, or service frequencies, could offer interesting avenues for research. In the literature, there is also little account of the physical restrictions at the ports in SA operations, such as tides or port drafts, as well as transshipment costs, which could be included in future modeling.

Finally, empirical research on the impact of the growing size of containerships on other stakeholders such as shippers and freight forwarders, and on empowering the economies of countries with a member or members in SAs would be also interesting areas for further research. Future studies should also extend the scope of research to include, in particular, findings from books and reports written by academics or practitioners.

Funding Open Access funding enabled and organized by Projekt DEAL.

Open Access This article is licensed under a Creative Commons Attribution 4.0 International License, which permits use, sharing, adaptation, distribution and reproduction in any medium or format, as long as you give appropriate credit to the original author(s) and the source, provide a link to the Creative Commons licence, and indicate if changes were made. The images or other third party material in this article are included in the article's Creative Commons licence, unless indicated otherwise in a credit line to the material. If material is not included in the article's Creative Commons licence and your intended use is not permitted by statutory regulation or exceeds the permitted use, you will need to obtain permission directly from the copyright holder. To view a copy of this licence, visit http://creativecommons.org/licen ses/by/4.0/.

\section{References}

Agarwal, R., and Ö. Ergun. 2008. Ship scheduling and network design for cargo routing in liner shipping. Transportation Science 42 (2): 175-196. https://doi.org/10.1287/trsc.1070.0205.

Agarwal, R., and Ö. Ergun. 2010. Network design and allocation mechanisms for carrier alliances in liner shipping. Operations Research 58 (6): 1726-1742. https://doi.org/10.1287/opre.1100.0848.

Alphliner. 2020. Alphaliner Top 100. https://alphaliner.axsmarine.com/PublicTop100/.

Alix, Y., B. Slack, and C. Comtois. 1999. Alliance or acquisition? Strategies for growth in the container shipping industry, the case of CP ships. Journal of Transport Geography 7 (3): 203-208. https:// doi.org/10.1016/S0966-6923(98)00048-9.

Álvarez-SanJaime, Ó., P. Cantos-Sánchez, R. Moner-Colonques, and J.J. Sempere-Monerris. 2013. Competition and horizontal integration in maritime freight transport. Transportation Research Part e: Logistics and Transportation Review 51: 67-81. https://doi.org/10.1016/j.tre.2012.12.008. 
Angeloudis, P., L. Greco, and M.G.H. Bell. 2015. Strategic maritime container transport design in oligopolistic markets. Transportation Research Procedia 9: 269-282. https://doi.org/10.1016/j.trpro. 2015.07.015.

Arslan, O., C. Archetti, O. Jabali, G. Laporte, and M. Grazia Speranza. 2020. Minimum cost network design in strategic alliances. Omega 96: 102079. https://doi.org/10.1016/j.omega.2019.06.005.

Asgari, N., R.Z. Farahani, and M. Goh. 2013. Network design approach for hub ports-shipping companies competition and cooperation. Transportation Research Part a: Policy and Practice 48: 1-18. https://doi.org/10.1016/j.tra.2012.10.020.

Bahinipati, B.K., A. Kanda, and S.G. Deshmukh. 2009. Horizontal collaboration in semiconductor manufacturing industry supply chain: An evaluation of collaboration intensity index. Computers \& Industrial Engineering 57 (3): 880-895. https://doi.org/10.1016/j.cie.2009.03.003.

Balci, G., I.B. Cetin, and M. Tanyeri. 2018. Differentiation of container shipping services in Turkey. Transport Policy 61: 26-35. https://doi.org/10.1016/j.tranpol.2017.10.004.

Bergantino, A.S., and A.W. Veenstra. 2002. Interconnection and co-ordination: An application of network theory to liner shipping. International Journal of Maritime Economics 4 (3): 231-248. https://doi. org/10.1057/palgrave.ijme.9100044.

Borch, O.J., and M. Solesvik. 2016. Partner selection versus partner attraction in R\&D strategic alliances: The case of the Norwegian Shipping Industry. International Journal of Technology Marketing 11 (4): 421-439.

Brooks, M.R. 2004. Guest editorial: Is liner shipping unique? Maritime Policy \& Management 31 (4): 257-258. https://doi.org/10.1080/0308883042000282516.

Brooks, M.R., and K.J. Button. 2006. Market structures and shipping security. Maritime Economics \& Logistics 8 (1): 100-120. https://doi.org/10.1057/palgrave.mel.9100145.

Cariou, P. 2008. Liner shipping strategies: An overview. International Journal of Ocean Systems Management 1 (1): 2-13.

Cariou, P., and P. Guillotreau. 2021. Capacity management by global shipping alliances: Findings from a game experiment. Maritime Economics \& Logistics. https://doi.org/10.1057/s41278-021-00184-9.

Caschili, S., F. Medda, F. Parola, and C. Ferrari. 2014. An analysis of shipping agreements: The cooperative container network. Networks and Spatial Economics 14 (3-4): 357-377. https://doi.org/10. 1007/s11067-014-9230-1.

Chao, S.-L., and C.-W. Lai. 2019. Comparing the efficiency of alliance members and independent liner carriers: A metafrontier analysis. Maritime Economics \& Logistics 21: 157-172. https://doi.org/10. 1057/s41278-017-0088-2.

Chen, J., and S. Yahalom. 2013. Container slot co-allocation planning with joint fleet agreement in a round voyage for liner shipping. Journal of Navigation 66 (4): 589-603. https://doi.org/10.1017/ S0373463313000192.

Chen, J., H. Zhen, and B. Zong. 2008. Improved vessel allocation model of liner shipping and its application for slot chartering under shipping alliance. Journal of Transportation Systems Engineering and Information Technology 8 (3): 120-125. https://doi.org/10.6119/JMST.201904_27(2).0001.

Chiu, R.H., and D.-H. Wang. 2019. Collaboration enhances utilization of production factors in container shipping industry. Journal of Marine Science and Technology 27: 81-90. https://doi.org/10.6119/ JMST.201904_27(2).0001.

Chung, K.H., and C.S. Ko. 2016. Collaborative ship planning with slot exchange in liner shipping. ICIC Express Letters 10: 2579-2585.

Clarkson Research. 2020. Seaborne Trade monitor report, vol. 7, Report No. 2, London, England.

Crotti, D., C. Ferrari, and A. Tei. 2019. Merger waves and alliance stability in container shipping. Maritime Economics \& Logistics. Advance Online Publication. https://doi.org/10.1057/ s41278-019-00118-6.

Cruijssen, F., W. Dullaert, and H. Fleuren. 2007. Horizontal cooperation in transport and logistics: A literature review. Transportation Journal 46 (3): 22-39.

Das, S.S. 2011. To partner or to acquire? A longitudinal study of alliances in the shipping industry. Maritime Policy \& Management 38 (2): 111-128. https://doi.org/10.1080/03088839.2011.556677.

Ding, J. 2009. Partner selection of strategic alliance for a liner shipping company using extent analysis method of fuzzy AHP. Journal of Marine Science and Technology 17 (2): 97-105.

Ding, J.F., and G.S. Liang. 2005. Using fuzzy MCDM to select partners of strategic alliances for liner shipping. Information Sciences 173 (1-3): 197-225. https://doi.org/10.1016/j.ins.2004.07.013. 
Dong, J.X., C.Y. Lee, and D.P. Song. 2015. Joint service capacity planning and dynamic container routing in shipping network with uncertain demands. Transportation Research Part b: Methodological 78: 404-421. https://doi.org/10.1016/j.trb.2015.05.005.

Dong, Y., M. Liu, and X. Shi. 2001. Verifying liner shipping alliance's stability by applying core theory. Research in Transportation Economics, Container Transport Operations 32 (1): 15-24. https://doi. org/10.1016/j.retrec.2011.06.002.

Doi, M., H. Ohta, and H. Itoh. 2000. A theoretical analysis of liner shipping conferences and strategic alliances. Review of Urban \& Regional Development Studies 12 (3): 228-249. https://doi.org/10. 1111/j.1467-940X.2000.00079.x.

Dulebenets, M.A. 2018. A comprehensive multi-objective optimization model for the vessel scheduling problem in liner shipping. International Journal of Production Economics 196: 293-318. https:// doi.org/10.1016/j.ijpe.2017.10.027.

El Kalla, M., D. Zec, and A. Jugović. 2017. Container ports competition in light of contemporary liner shipping market dynamics. Pomorstvo 31: 128-136. https://doi.org/10.31217/p.31.2.7.

Evangelista, P., and A. Morvillo. 1999. Alliances in liner shipping: An instrument to gain operational efficiency or supply chain integration? International Journal of Logistics Research and Applications 2 (1): 21-38. https://doi.org/10.1080/13675569908901570.

Evangelista, P., and A. Morvillo. 2000. Cooperative strategies in international and Italian liner shipping. Maritime Economics \& Logistics 2 (1): 1-16. https://doi.org/10.1057/ijme.2000.3.

Ferrari, C., F. Parola, and M. Benacchio. 2008. Network economies in liner shipping: The role of home markets. Maritime Policy \& Management 35 (2): 127-143. https://doi.org/10.1080/0308883080 1956789.

Fransoo, J.C., and C.Y. Lee. 2013. The critical role of ocean container transport in global supply chain performance. Production and Operations Management 22 (2): 253-268. https://doi.org/10.1111/j. 1937-5956.2011.01310.x.

Fusillo, M. 2006. Some notes on structure and stability in liner shipping. Maritime Policy \& Management 33 (5): 463-475. https://doi.org/10.1080/03088830601020653.

Graham, M.G. 1998. Stability and competition in intermodal container shipping: Finding a balance. Maritime Policy \& Management 25 (2): 129-147. https://doi.org/10.1080/03088839800000024.

Greve, H.R., H. Mitsuhashi, and J.A.C. Baum. 2013. Greener pastures: Outside options and strategic alliance withdrawal. Organization Science 24 (1): 79-98. https://doi.org/10.1287/orsc.1110.0733.

González-Laxe, F., I. Novo-Corti, and D.M. Pociovalisteanu. 2016. New maritime alliances and competition in a new economic environment. Traffic \& Transportation 28 (3): 311-320. https://doi.org/10. 7307/ptt.v28i3.1749.

Gutiérrez, E., S. Lozano, and S. Furió. 2014. Evaluating efficiency of international container shipping lines: A bootstrap DEA approach. Maritime Economics \& Logistics 16 (1): 55-71. https://doi.org/ 10.1057/mel.2013.21.

Ha, Y.S., and J.S. Seo. 2017. An analysis of the competitiveness of major liner shipping companies. The Asian Journal of Shipping and Logistics 33 (2): 53-60. https://doi.org/10.1016/j.ajs1.2017.06.002.

Hapag-Lloyd. 2019. HMM to join THE Alliance-Carrier will be fourth member-besides HapagLloyd, Ocean Network Express (ONE) and Yang Ming, Press Release July 1, 2019. https://www. hapag-lloyd.com/en/company/press/releases/2019/07/hmm-to-join-the-alliance-.html.

Haralambides, H.E. 1996. The economics of bulk shipping pools. Maritime Policy and Management 23 (3): 221-237.

Haralambides, H.E. 2019. Gigantism in container shipping, ports and global logistics: A timelapse into the future. Maritime Economics \& Logistics 21 (1): 1-60. https://doi.org/10.1057/ s41278-018-00116-0.

Heaver, T., H. Meersman, F. Moglia, and E. Van De Voorde. 2000. Do mergers and alliances influence European shipping and port competition? Maritime Policy \& Management 27 (4): 363-373. https:// doi.org/10.1080/030888300416559.

Hirata, E. 2017. Contestability of container liner shipping market in alliance era. The Asian Journal of Shipping and Logistics 33 (1): 27-32. https://doi.org/10.1016/j.ajs1.2017.03.004.

Huang, S.T. 2016. Key factors analysis of strategic alliances in container liner shipping industry. Transport \& Logistics: the International Journal 16 (39): 1-8.

Huang, S.T., and S. Yoshida. 2013. Analysis of key factors for formation of strategic alliances in liner shipping company: Service quality perspective on Asia/Europe route after global economic crisis. International Journal of Social, Behavioral, Educational, Economic, Business and Industrial Engineering 7 (6): 1414-1418. 
Kale, P., and H. Singh. 2009. Managing strategic alliances: What do we know now, and where do we go from here? Academy of Management Perspectives 23 (3): 45-62. https://doi.org/10.5465/amp. 2009.43479263.

Killing, J.P. 1988. Understanding alliances: the role of task and organizational complexity. In Cooperative Strategies in International Business, ed. F.J. Contractor and P. Lorange. Lexington: Lexington Books.

Lei, D., J.W. Slocum, and R.A. Pitts. 1997. Building cooperative advantage: Managing strategic alliances to promote organizational learning. Journal of World Business 32 (3): 203-223. https://doi.org/10. 1016/S1090-9516(97)90008-0.

Lee, E.S. 2019. Improving a Firm's performance within a strategic shipping alliance. The Asian Journal of Shipping and Logistics 35: 213-219.

Lee, H., M. Boile, S. Theofanis, and S. Choo. 2012. Modeling the oligopolistic and competitive behavior of carriers in maritime freight transportation networks. Social and Behavioral Sciences 54: 10801094. https://doi.org/10.1016/j.sbspro.2012.09.823.

Lee, C.Y., and D.P. Song. 2017. Ocean container transport in global supply chains: Overview and research opportunities. Transportation Research Part b: Methodological 95: 442-474. https://doi. org/10.1016/j.trb.2016.05.001.

Li, J., G. Rong, and Y. Feng. 2015. Request selection and exchange approach for carrier collaboration based on auction of a single request. Transportation Research Part e: Logistics and Transportation Review 84: 23-39. https://doi.org/10.1016/j.tre.2015.09.010.

Lin, D.Y., C.C. Huang, and M. Ng. 2017. The coopetition game in international liner shipping. Maritime Policy \& Management 44 (4): 474-495. https://doi.org/10.1080/03088839.2017.1295325.

Liu, J., and J. Wang. 2019. Carrier alliance incentive analysis and coordination in a maritime transport chain based on service competition. Transportation Research Part e: Logistics and Transportation Review 128: 333-355. https://doi.org/10.1016/j.tre.2019.06.009.

Lu, H.A., J. Cheng, and T.S. Lee. 2006. An evaluation of strategic alliances in liner shipping-an empirical study of CKYH. Journal of Marine Science and Technology 14 (11): 202-212.

Lu, H.A., C.W. Chu, and P.Y. Che. 2010. Slot allocation planning for an alliance service with ship fleet sharing. Asia Pacific Management Review 15 (3): 325-339.

Meng, Q., S. Wang, H. Andersson, and K. Thun. 2013. Containership routing and scheduling in liner shipping: Overview and future research directions. Transportation Science 48 (2): 265-280. https://doi.org/10.1287/trsc.2013.0461.

Merk, O. 2018. The impact of alliances in container shipping. Paris: International Transport Forum/ OECD.

Merk, O., and A. Teodoro. 2022. Alternative approaches to measuring concentration in liner shipping. Maritime Economics \& Logistics.

Midoro, R., and A. Pitto. 2000. A critical evaluation of strategic alliances in liner shipping. Maritime Policy \& Management 27 (1): 31-40. https://doi.org/10.1080/030888300286662.

Mitsuhashi, H., and H.R. Greve. 2009. A matching theory of alliance formation and organizational success: Complementarity and compatibility. Academy of Management Journal 52 (2): 975995. https://doi.org/10.5465/amj.2009.44634482.

Mulder, J., and R. Dekker. 2014. Methods for strategic liner shipping network design. European Journal of Operational Research 235 (2): 367-377. https://doi.org/10.1016/j.ejor.2013.09.041.

Nair, R. 2016. Study on economic regulation of collaborative strategies among container shipping companies following repeal of European Union Regulation 4056/86. The Asian Journal of Shipping and Logistics 32 (2): 89-97. https://doi.org/10.1016/j.ajsl.2016.05.002.

Notteboom, T.E. 2006. The time factor in liner shipping services. Maritime Economics \& Logistics 8 (1): 19-39. https://doi.org/10.1057/palgrave.mel.9100148.

Notteboom, T.E., F. Parola, G. Satta, and A.A. Pallis. 2017. The relationship between port choice and terminal involvement of alliance members in container shipping. Journal of Transport Geography 64: 158-173. https://doi.org/10.1016/j.jtrangeo.2017.09.002.

Ocean alliance Federal Maritime Commission agreement. 2019. Federal Maritime Commission. https://www2.fmc.gov/FMC.Agreements.Web/Public/AgreementHistory/1214.

Panayides, P.M., and K. Cullinane. 2002. Competitive advantage in liner shipping: A review and research agenda. International Journal of Maritime Economics 4 (3): 189-209. https://doi.org/ $10.1057 /$ palgrave.ijme.9100045.

Panayides, P., and R. Wiedmer. 2011. Strategic alliances in container liner shipping. Research in Transportation Economics 32 (1): 25-38. https://doi.org/10.1016/j.retrec.2011.06.008. 
Parola, F., S. Caschili, F.R. Medda, and C. Ferrari. 2014. Measuring the scope of inter-firm agreements in the container shipping industry: An empirical assessment. International Journal of Shipping and Transport Logistics 6 (5): 466-487. https://doi.org/10.1504/IJSTL.2014.064571.

Qiu, X., E.Y.C. Wong, and J.S.L. Lam. 2018. Evaluating economic and environmental value of liner vessel sharing along the maritime silk road. Maritime Policy \& Management 45: 336-350. https://doi.org/10.1080/03088839.2018.1437285.

Quartieri, F. 2017. Are vessel sharing agreements pro-competitive? Economics of Transportation 11-12: 33-48. https://doi.org/10.1016/j.ecotra.2017.10.004.

Rau, P., and S. Spinler. 2016. Investment into container shipping capacity: A real options approach in oligopolistic competition. Transportation Research Part e: Logistics and Transportation Review 93: 130-147. https://doi.org/10.1016/j.tre.2016.05.012.

Rau, P., and S. Spinler. 2017. Alliance formation in a cooperative container shipping game: Performance of a real options investment approach. Transportation Research Part e: Logistics and Transportation Review 101: 155-175. https://doi.org/10.1016/j.tre.2017.02.005.

Rimmer, P.J. 1998. Impact of global shipping alliances on pacific rim seaports. Journal of Maritime Studies 98: 1-29. https://doi.org/10.1080/07266472.1998.10878505.

Ryoo, D.K., and H.A. Thanopoulou. 1999. Liner alliances in the globalization era: A strategic tool for Asian container carriers. Maritime Policy \& Management 26 (4): 349-367. https://doi.org/10. 1080/030888399286790.

Seok-Min, L. 1998. Economies of scale in container shipping. Maritime Policy \& Management 25 (4): 361-373. https://doi.org/10.1080/03088839800000059.

Sheppard, E.J., and D. Seidman. 2001. Ocean shipping alliances: The wave of the future? International Journal of Maritime Economics 3 (4): 351-367. https://doi.org/10.1057/palgrave.ijme. 9100025.

Shi, X., and S. Voss. 2008. Iterated cooperation and possible deviations between liner shipping carriers based on non-cooperative game theory. Journal Transportation Research Record: Journal of the Transportation Research Board 2066 (1): 60-70.

Sjostrom, W. 1989. Collusion in ocean shipping: A test of monopoly and empty core models. Journal of Political Economy 97 (5): 1160-1179.

Sjostrom, W. 1993. Antitrust immunity for shipping conferences: An empty core approach. The Antitrust Bulletin 38 (2): 419-423.

Slack, B., C. Comtois, and R. McCalla. 2002. Strategic alliances in the container shipping industry: A global perspective. Maritime Policy \& Management 29 (1): 65-76. https://doi.org/10.1080/03088 830110063694.

Solesvik, M., and P. Westhead. 2010. Partner selection for strategic alliances: Case study insights from the maritime industry. Industrial Management \& Data Systems 110 (6): 841-860.

Song, D.P., and J. Carter. 2009. Empty container repositioning in liner shipping. Maritime Policy \& Management 36 (4): 291-307. https://doi.org/10.1016/j.tre.2015.09.007.

Song, D.W., and P.M. Panayides. 2002. A conceptual application of cooperative game theory to liner shipping strategic alliances. Maritime Policy \& Management 29 (3): 285-301. https://doi.org/10. 1080/03088830210132632.

Soppé, M., F. Parola, and A. Frémont. 2009. Emerging inter-industry partnerships between shipping lines and stevedores: From rivalry to cooperation? Journal of Transport Geography 17 (1): 10-20. https://doi.org/10.1016/j.jtrangeo.2008.04.006.

Sys, C. 2009. Is the container liner shipping industry an oligopoly? Transport Policy 16 (5): 259-270. https://doi.org/10.1016/j.tranpol.2009.08.003.

Tan, B.S.Y., and V.V. Thai. 2014. Knowledge sharing within strategic alliance networks and its influence on firm performance: The liner shipping industry. International Journal of Shipping and Transport Logistics 6 (4): 387-411. https://doi.org/10.1504/IJSTL.2014.062902.

Tang, O., and P. Sun. 2018. Anti-competition of ocean shipping alliances: A legal perspective. Maritime Business Review 3 (1): 4-19. https://doi.org/10.1108/MABR-08-2017-0023.

Thanopoulou, H.A., D.K. Ryoo, and T.W. Lee. 1999. Korean liner shipping in the era of global alliances. Maritime Policy \& Management 26 (3): 209-229. https://doi.org/10.1080/030888399286853.

THE alliance Federal Maritime Commission agreement. 2019. Federal Maritime Commission. https:// www2.fmc.gov/FMC.Agreements.Web/Public/AgreementHistory/1912.

Ting, S.C., and G.H. Tzeng. 2003. Ship scheduling and service network integration for liner shipping companies and strategic alliances. Journal of the Eastern Asia Society for Transportation Studies 5: 765-777. 
UNCTAD. 2020. Review of maritime transport 2020. New York: United Nations Publications.

Verstrepen, S., M. Cools, F. Cruijssen, and W. Dullaert. 2009. A dynamic framework for managing horizontal cooperation in logistics. International Journal of Logistics Systems and Management 5 (3/4): 228-248. https://doi.org/10.1504/IJLSM.2009.022497.

Wang, M. 2015. The formation of shipping conference and rise of shipping alliance. International Journal of Business Administration 6 (5): 22-36. https://doi.org/10.5430/ijba.v6n5p22.

Wang, Z., H. Hu, Q. Zeng, and X. Li. 2016. Profit sharing and the stability of shipping alliances based on game theory. Journal of Transport Economics and Policy (JTEP) 50 (3): 245-261.

Wang, H., Q. Meng, and X. Zhang. 2014. Game-theoretical models for competition analysis in a new emerging liner container shipping market. Transportation Research Part b: Methodological 70: 201-227. https://doi.org/10.1016/j.trb.2014.09.006.

Yang, D., M. Liu, and X. Shi. 2011. Verifying liner Shipping Alliance's stability by applying core theory. Research in Transportation Economics 32 (1): 15-24. https://doi.org/10.1016/j.retrec.2011.06.002.

Yap, W.Y. 2014. P3 Alliance and its implications on contestability in major gateway ports in North America. Transportation Journal 53: 499-515. https://doi.org/10.5325/transportationj.53.4.0499.

Yap, W.Y., and S.M. Zahraei. 2018. Liner shipping alliances and their impact on shipping connectivity in Southeast Asia. Maritime Business Review 3 (3): 243-255. https://doi.org/10.1108/ MABR-05-2018-0018.

Zaheer, A., and N. Venkatraman. 1995. Relational governance as an inter-organizational strategy: An empirical test of the role of trust in economic exchange. Strategic Management Journal 16 (5): 373-392. https://doi.org/10.1002/smj.4250160504.

Zhang, H., L. Lu, and X. Wang. 2019. Profits comparison between alliance mode and non-alliance mode of empty containers repositioning of liner companies. Systems Science \& Control Engineering 7: 125-132. https://doi.org/10.1080/21642583.2019.1585302.

Zheng, J., Z. Gao, D. Yang, and Z. Sun. 2015. Network design and capacity exchange for liner alliances with fixed and variable container demands. Transportation Science 49: 886-899. https://doi.org/10. 1287/trsc.2014.0572.

Zheng, S., R.R. Negenborn, and X. Zhu. 2017. Cost allocation in a container shipping alliance considering economies of scale: A CKYH alliance case study. International Journal of Shipping and Transport Logistics 9: 449-474. https://doi.org/10.1504/IJSTL.2017.084827.

Publisher's Note Springer Nature remains neutral with regard to jurisdictional claims in published maps and institutional affiliations. 